\title{
In Vitro Induction of Callus and Flowers in Immature Oil Palm Inflorescences
}

\author{
Marcília Gabriella Tavares Monteiro (Corresponding author)
}

Laboratório de Bioquímica, Universidade Federal Rural da Amazônia, Belém, Pará, Brasil. E-mail: gabytmonteiro@gmail.com

\section{Joanne Moraes de Melo Souza}

Laboratório de Biotecnologia, Universidade Federal Rural da Amazônia, Belém, Pará, Brasil.

Hugo Alves Pinheiro

Laboratório de Bioquímica, Universidade Federal Rural da Amazônia, Belém, Pará, Brasil.

Oriel Filgueira de Lemos

Laboratório de Biotecnologia Vegetal, Embrapa Amazônia Oriental, Belém, Pará, Brasil.

Raimundo Parente de Oliveira

Embrapa Amazônia Oriental, Belém, Pará, Brasil.

Bruno Barbosa Boás

Laboratório de Botânica, Embrapa Amazônia Oriental, Belém, Pará, Brasil.

Fernanda Ilkiu Borges de Souza

Laboratório de Botânica, Embrapa Amazônia Oriental, Belém, Pará, Brasil.

Received: Dec. 23, 2019

doi:10.5296/jas.v8i4.16114
Accepted: Nov. 5, $2020 \quad$ Published: Nov. 22, 2020

URL: https://doi.org/10.5296/jas.v8i4.16114 


\section{Abstract}

This work aimed to investigate the effects of different combinations of auxin $(0,225$ and 450 $\mu \mathrm{M}$ Picloram) and Murashige and Skoog salts (50\% and 100\% MS salt concentrations, respectively named as $1 / 2 \mathrm{MS}$ and MS) in mediate the induction of callus and flowers from immature inflorescences (developmental stages I-9, I-12 and I-15) of the oil palm BRS Manicoré hybrid. In I-9 inflorescence explants, the rate of callus induction was $17 \%$ higher in $1 / 2$ MS than in MS; while in both I-12 and I-15 inflorescence explants, callus induction was over than $95 \%$ regardless of the MS salt concentration. The higher rate of callus induction in I-9 inflorescences was mediated by $450 \mu \mathrm{M}$ Picloram, while the callus induction rates for either I-12 or I-15 inflorescences were higher than 92\% regardless of Picloram concentration. Floral induction was lower in I-9 inflorescence explants (45\% floral induction rate) than in both I-12 and I-15 inflorescence explants (floral induction rate higher than 90\%). Our results suggest that Picloram $(450 \mu \mathrm{M})$ and MS salts concentrations ( $1 / 2 \mathrm{MS})$ led to the highest rates of calluses and flowers induction in younger inflorescence explants (I-9); however, the medium composition is indifferent on callus and flower induction in I-12 and I-15 inflorescences.

Keywords: auxin, Elaeis oleifera x E. guineensis, MS salts, Picloram

\section{Introduction}

African oil palm (Elaeis guineensis Jacq.) cultivations in Brazil and Latin America have suffered from the occurrence of lethal yellowing (LY), an unknown-cause anomaly that already devastated thousands of hectares with oil palm. In Brazil, the LY has been affecting continuously several areas since the first reported case in the country (De Franqueville, 2003). Therefore, the development of LY - resistant oil palm cultivars has been addressed through crop breeding. In this context, the BRS - Manicoré hybrid, a result of interspecific hybridization between the African (E. guineensis) and American (E. oleifera (Kunth) Cortés) oil palm species, brings together desirable agronomic traits, such as high yield, pests resistance, LY resistance, high content of unsaturated fatty acids in fruits and short stipe growth (Cunha et al., 2009). In Brazil, the viability of planting oil palm hybrids (such as BRS - Manicoré) in areas previously devastated by LY has been observed, highlighting the resistance of this plant material to LY (Cunha and Lopes, 2010).

The natural vegetative propagation of oil palm occurs through seeds since this species does not produce axillary shoots - by having only one apex of growth - and, therefore, cannot be multiplied vegetatively by tillering (Rajesh et al., 2003). Concerning interspecific hybrids, a low seed germination rate around $30 \%$ and $36 \%$ is commonly observed (Angelo et al., 2007; Maquiné et al., 2012). Despite this, the seedlings of hybrids, including BRS - Manicoré, have been produced from pre-germinated seeds, a process that takes about 150 days from the fruit harvesting and processing to embryonic axis emergence (Lopes, 2013). Additionally, the generated plants present high genetic variability, and this is one of the main yields limiting factors in most of the commercial cultivated areas with oil palm (Viegas and Muller 2000).

Considering that oil palm presents highly heterozygous plants, heterogeneous populations, and monopodial growth, the in vitro clonal propagation raises as a suitable alternative to 
produce oil palm hybrid seedling on a large-scale (Teixeira et al., 1995; Rajesh et al., 2003). Thus, one can expect that more uniform and healthy BRS - Manicoré seedlings can be produced from a single explant and in a lower timeframe as compared to the traditional nursery methods (Erig and Schuch, 2005).

Different plant tissues have been used on clonal propagation, including the inflorescences (Teixeira et al., 1994; Karun et al., 2004; Campos et al., 2007). In oil palm micro propagation, the explants commonly used are zygotic embryos (Teixeira et al., 1995), immature inflorescences (Teixeira et al., 1994), immature leaves, and tertiary and quaternary roots (Eeuwens et al., 2002). The micro propagation of the oil palm BRS - Manicoré hybrid is still unknown and in this research we hypothesize that immature inflorescences may be an adequate explant to start in vitro cultivations of this hybrid. Our expectations are based on the totipotence of immature inflorescence cells, which also should present low levels of contamination by microorganisms since they are protected by floral spaths. We also hypothesize that BRS - Manicoré micro propagation may be achieved through somatic embryogenesis and in this context we believe that auxins may be crucial due to its effects on cell de-differentiation (Elhiti et al., 2013). The most used auxins for somatic embryogenesis induction are 2,4-dichlorophenoxyacetic acid (2,4-D), 4-amino-3,5,6-trichloropicolinic acid (Picloram) and 3,6-dichloro-2- methoxybenzoic acid (Dicamba). These chemicals may act on gene expression and in cell division and expansion, leading to callogenesis, embryogenesis and organogenesis (Krikorian, 1991).

Thus, this study was carried out to evaluate the ability of immature inflorescences in inducing in vitro callus and flowers in oil palm BRS - Manicoré hybrid growing at two concentrations of Murashige and Skoog salts (total concentration, MS; or halved concentration, $1 / 2 \mathrm{MS}$ ) and three concentrations of auxin $(0 ; 225$ and $450 \mu \mathrm{M}$ Picloram). The outcome of this work will further support studies on in vitro oil palm regeneration via somatic embryogenesis, aiming at producing BRS - Manicoré seedlings on a large scale.

\section{Materials and Methods}

\subsection{Plant Material}

Immature female inflorescences of oil palm BRS - Manicoré hybrid at different developmental stages were used as explants. The inflorescences were collected in Moju, state of Pará, northern Brazil ( $01^{\circ} 53$ '02 "S and 48 46' 08" W) and identified according to the corresponding phyllotaxis order (leaf number) arranged throughout the plant as follows: I-9, inflorescence from the ninth leaf; I-12, inflorescence from the $12^{\text {th }}$ leaf; and I-15, inflorescence from the $15^{\text {th }}$ leaf.

At the laboratory, inflorescences still containing spathe were washed with neutral liquid soap, then dipped in $2.5 \%$ sodium hypochlorite and rinsed in deionized water. The outer and inner spathes were removed and inflorescences were immersed in $70 \%(\mathrm{v} / \mathrm{v})$ ethanol for $1 \mathrm{~min}$ and subsequently in sodium hypochlorite $(2.5 \%)$ for $15 \mathrm{~min}$. Finally, the inflorescences were washed three times in sterile distilled water before inoculation in culture mediums. All sterilization procedures were performed in a laminar flow cabinet. 


\subsection{Growth Conditions and Experimental Design}

The I-9, I-12 and I-15 inflorescences were cross-sectioned and sections were inoculated in MS medium (Murashige and Skoog, 1962) containing either a total concentration (MS) or halved concentration $(1 / 2 \mathrm{MS})$ of salts combined with three concentrations of auxin $(0 ; 225$ and $450 \mu \mathrm{M}$ Picloram). Therefore, the experiment consisted of the following culture mediums: $\mathrm{MS}+0 \mu \mathrm{M}$ Picloram; MS + $225 \mu \mathrm{M}$ Picloram; MS $+450 \mu \mathrm{M}$ Picloram; $1 / 2 \mathrm{MS}+0 \mu \mathrm{M}$ Picloram; $1 / 2 \mathrm{MS}+225 \mu \mathrm{M}$ Picloram; $1 / 2 \mathrm{MS}+450 \mu \mathrm{M}$ Picloram. All culture mediums were supplemented with $30 \mathrm{~g} \mathrm{~L}^{-1}$ sucrose, $0.3 \%(\mathrm{w} / \mathrm{v})$ phytagel, and $2.5 \mathrm{~g} \mathrm{~L}^{-1}$ activated carbon. The medium $\mathrm{pH}$ was adjusted to 5.8 before autoclaving at $120{ }^{\circ} \mathrm{C}$ for $20 \mathrm{~min}$. The explants were inoculated in flasks containing $40 \mathrm{~mL}$ culture medium, which were placed in a growth chamber at $25^{\circ} \mathrm{C}$ under darkness.

The experiment was performed in a completely randomized design, in a $3 \times 2 \times 3$ factorial scheme (inflorescence developmental stages $\mathrm{x}$ MS medium salt concentration $\mathrm{x}$ Picloram concentrations), totalling 18 treatments and six replications. Each experimental unit consisted of a culture flask containing five rachilla sections.

\subsection{Assessments}

Evaluations were carried out 45 days after inoculation by assessing the explants contamination and oxidation rates and determining the callus and flower induction rates. All data were expressed in percentage, calculated as the total number of occurrences in relation to total number of explants per flask.

Histological analyses of the cultures were performed by fixing the samples in $70 \%$ FAA (formaldehyde, ethyl alcohol, and acetic acid) for $24 \mathrm{~h}$ followed by progressive ethanol dehydration $(70 \%-80 \%-90 \%-100 \%)$. The time of incubation in each ethanol concentration was about $30 \mathrm{~min}$. The samples were then transferred to a pre-infiltration solution containing 95\% ethanol and Leica historesin (1:1, v/v) for $24 \mathrm{~h}$. After that, all samples were immersed in an infiltration solution for at least $24 \mathrm{~h}$. The samples were embedded in Leica historesin and sectioned using a manual microtome. The samples were stained with $0.05 \%$ blue toluidine prior to glass slide setting.

\subsection{Statistics}

The data did not present normal distribution even after arcsine transformation (Fischer 1922, Zubin 1935). Therefore, all data set were submitted to non-parametric analysis by the Kruskall Walls method, somehow the differences between treatments were performed by Dunn's test $(\mathrm{p}<0.05)$. Data analysis was accomplished by using SAS software (SAS Institute Inc., Cary, USA).

\section{Results and Discussion}

\subsection{Explant Contamination and Oxidation}

The rate of explant contamination was only about 3.5\%. Hence, this indicates that the explants presented low endogenous contamination by microorganisms. Moreover, the use of 
ethanol and sodium hypochlorite was efficient in promoting the surface asepsis of explants without impairing their morphogenic responses to callus and flower induction treatments.

Irrespective of the Picloram concentrations (Figure 1A), a high rate of explant oxidation (> $61 \%$ ) was observed in MS mediums independently of the inflorescence developmental stage and salts concentration. In explants originated from I-9 and I-12 inflorescences, the oxidation rates were not influenced by MS salts concentration. However, the oxidation rate in I-15 inflorescence explants was 39\% higher in $1 / 2$ MS than in MS medium (Figure 1A).

The overall effects of Picloram in attenuating the explants oxidation independently of MS medium salts concentration are shown in Figure 1B. The addition of $225 \mu \mathrm{M}$ Picloram was sufficient to reduce the oxidation of explants obtained from both I-9 and I-15 inflorescences by $25 \%$ and $29 \%$, respectively, while a higher concentration of this compound $(450 \mu \mathrm{M})$ was necessary to reduce the oxidation rate in I-12 inflorescence explants by $15 \%$. When explant oxidation rates were evaluated regardless of inflorescence developmental stage (Figure 1C), one can note that oxidation rate was higher in the absence of Picloram. The lower oxidation rates were observed in MS medium containing $225 \mu \mathrm{M}$ Picloram (Figure 1C).

The explant oxidation may be a response to phenolic compounds, which seems to be common in vitro oil palm cultivation (Silva et al., 2012). According to Teixeira et al. (1994), the use of activated carbon in the MS medium may significantly reduce phenolic oxidation. Likewise, Thomas (2008) reported the benefits of activated carbon on plant growth and development due to its potential to adsorb inhibitory substances in the culture medium. In this experiment, however, the activated carbon did not prevent explant oxidation but data shows that explant oxidation tended to be lower in the presence of Picloram, particularly in the MS mediums. Although this result suggests that Picloram may attenuate explant oxidation, one must to be cautious, however, because such antioxidant effect has not been earlier described.

\subsection{Callus Induction}

In this experiment we observed that explants oxidation in inflorescences at all developmental stages did not affect callus induction, as also previously observed by Teixeira et al. (1994). Therefore, such friable, beige - colored calluses can be observed in oxidized BRS - Manicoré explants in Figure 2 and 4. Comparatively, Silva et al. (2012) observed high occurrence of phenolic oxidation in explants from some oil palm genotypes even in the presence of activated carbon $\left(2.5 \mathrm{~g} \mathrm{~L}^{-1}\right)$; however, the oxidation level was not harmful to in vitro morphogenesis. Teixeira et al. (1993) used immature zygotic embryos of oil palm in a culture medium to induce callus formation and showed that the presence of $0.3 \%$ activated carbon attenuated the oxidation of explants by the adsorption of part of the 2,4-D present in the MS medium.

In I-9 inflorescence explants, the callus induction rate was $17 \%$ higher in $1 / 2$ MS than in MS medium (Figure 3A). On the other hand, in explants from both I-12 and I-15 inflorescences, the callus induction rates were higher than $95 \%$ regardless of the MS salt concentrations in the culture medium (Figure 3A). Therefore, the results evidence that the highest callus induction did not occur in the youngest tissues (I-9), as previously reported by Pierik (1990). 
The callus induction is commonly mediated by auxins (Ozias-Akins; Vasil, 1985). Auxins are substances involved with de-differentiation and redifferentiation mechanisms in most models of somatic embryogenesis (Thuzar et al., 2011). In indirect embryogenesis, which involves the formation of callus, the de-differentiation occurs prior to the cell redifferentiation via genetic reprogramming. At this point, the physiological stage of the explant and plant growth regulator type and concentration are crucial because they act as chemical signals to activate specific pattern of gene expression (Guerra et al., 2016).

According to Soh et al. (2011), the rate of callus induction and callus growth seems to be slower in E. guineensis than in other plant species, even under similar cultivation conditions, indicating that the callus induction follows a specific pattern for each species. Besides that, different rates of callus induction have been reported for different E. guineensis genotypes, indicating that callus induction in African oil palm is a genotype-specific response (Corrêa et al. 2015). Furthermore, Balzon et al. (2013) observed that the frequency of embryogenic callus induction in oil palm growing in culture medium containing both Picloram $(450 \mu \mathrm{M})$ and activated carbon $\left(2.5 \mathrm{~g} \mathrm{~L}^{-1}\right)$ reached $97.5 \%$ of zygotic embryos in the MS medium, while the response was $79.4 \%$ in the MS medium supplemented with 2,4-D and activated carbon.

In this study, the Picloram - mediated induction of callus was only evident in explants from the youngest inflorescences (I-9), particularly at the concentration of $450 \mu \mathrm{M}$ Picloram (Figure 3B). In the most mature inflorescences (I-12 and I-15), the callus induction rates were higher than $92 \%$ regardless of Picloram concentration in the culture medium (Figure 3B). In addition, it was demonstrated that the callus induction rate in the absence of Picloram was lower in MS than in $1 / 2$ MS medium, while no significant effect of the MS salts concentration was observed in the presence of 225 or $450 \mu \mathrm{M}$ Picloram (Figure 3C). These results indicate that all explants evaluated in this study presented a sufficient concentration of endogenous auxins to induce callus growth. Furthermore, since the effect of Picloram in stimulating significant increases in the callus induction rate was limited to I-9 inflorescences, it can be inferred that these younger inflorescences must have a lower endogenous concentration of auxins than more mature inflorescences (I-12 and I-15). Therefore, the addition of Picloram to the culture medium must have properly compensated for the lower endogenous concentration of auxin in I-9 inflorescences.

\subsection{Flower Induction}

The differentiation of inflorescences started seven days after explants inoculation in the respective culture mediums. After 45 days of growth under darkness, numerous calluses (Figure 4A) and flowers (Figure 4B) were evident in all treatments, even in explants presenting pronounced oxidation (Figure 4C and 4D). Then, explants containing flowers and calluses (Figure 5A) were subjected to histological traits. From the results we evidenced the presence of parenchyma, randomly distributed bundles-sheath, and vacuolated cells in the calluses (Figure 5B and 5D). Such structures showed the same pattern as commonly observed in monocotyledons. Further, we also confirmed the presence of floral structures initiation with three verticils (Figure 5C).

Floral induction was observed in the explants originated from inflorescences at all 
developmental stages and it was irrespective of the MS salts concentration in the culture medium (Figure 6A). However, the average rates of floral induction were lower in explants originated from the youngest inflorescences (I-9, with $45 \%$ of flowers) than those from more mature inflorescences (I-12 and I-15, higher than $90 \%$ of flowers). Therefore, the stage of maturation of the explant significantly influenced in vitro differentiation of flowers in BRS Manicoré hybrid. A similar result was observed in Bactris gasipaes, in which the formation of floral structures was higher in more mature inflorescences (Steinmacher et al. 2007). By contrast, Carvalho (2009) demonstrated that the developmental stage of E. guineensis inflorescence affects the percentage of rachilla with flowers, somehow the higher average was observed in explants obtained from younger inflorescences.

When the youngest inflorescences (I-9) were used as explants, the absence of Picloram in the MS medium completely inhibited the floral induction (Figure 6B). In such explants, floral induction significantly increased as a function of Picloram concentration in the MS medium, which reached $36 \%$ and $98 \%$, respectively, at $225 \mu \mathrm{M}$ and $450 \mu \mathrm{M}$ Picloram (Figure 6B).

There was no interaction between medium composition (MS and $1 / 2$ MS) and Picloram concentrations $(0 ; 225 \mu \mathrm{M}$ and $450 \mu \mathrm{M})$. However, a clear upward trend in flower induction rates was observed in response to increases in Picloram concentration in the culture medium (Figure 6C).

In general, our results demonstrate the importance of Picloram in underlying in vitro floral induction in explants originated from oil palm BRS - Manicoré inflorescences, particularly in younger ones. It was also evidenced that the floral induction is dependent on the concentration of Picloram present in the MS medium. Comparatively, Teixeira et al. (1994) observed that the addition of 2,4-D auxin $(475 \mu \mathrm{M})$ to the MS medium induced the development of floral structures in oil palm inflorescences (Psifera). According to Teixeira et al. (1994) and Zaid and Tisserat (1983), the development of these floral structures is a consequence of a high degree of inflorescence architecture determination, thus presenting less sensitivity to in vitro stimuli.

\section{Conclusions}

1. The oxidation of explants - even in the presence of activated carbon in the MS medium did not prevent in vitro induction of callus and flower in all inflorescences tested.

2. The explants obtained from I-9, I-12 and I-15 inflorescences are suitable to induce in vitro callus and flower formation, and however, the highest rates of floral induction were observed in the I-12 and I-15 explants regardless of medium composition.

3. A significant effect of Picloram in inducing in vitro calluses and flowers was evident only in younger inflorescence explants (I-9) growing in $1 / 2 \mathrm{MS}$ medium containing $450 \mu \mathrm{M}$ Picloram. 

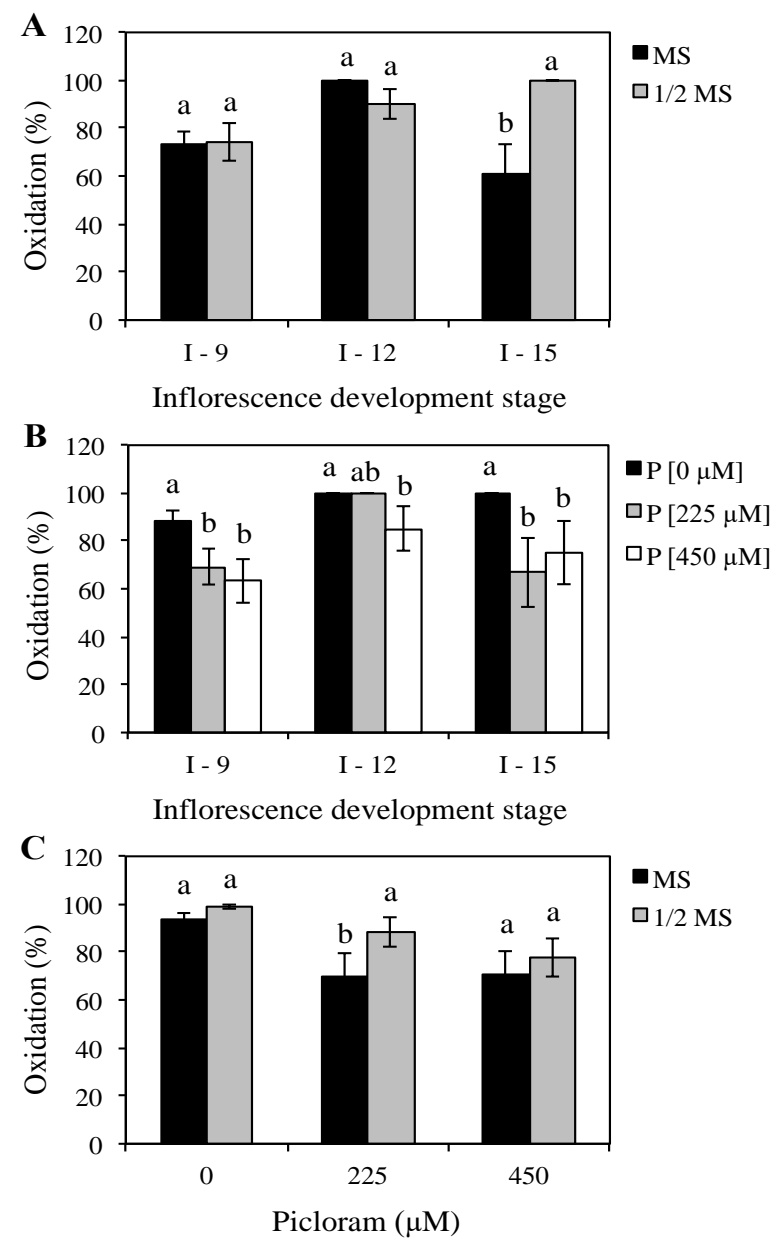

Figure 1. Effects of salt (total concentration, MS; or halved concentration, $1 / 2 \mathrm{MS}$ ) and Picloram $(0 ; 225$ and $450 \mu \mathrm{M})$ concentrations on oxidation rates of oil palm BRS - Manicoré explants obtained from inflorescences at different stages of development (I-9, I-12 and I-15).

The data are presented as means \pm SD $(n=6)$. In Figures $1 A$ and $1 B$, lowercase letters indicate significant differences between treatments with different MS medium compositions (A) or Picloram concentration (B) at the same stage of floral development. In Figure 1C, lowercase letters denote significant differences between treatments with different MS medium compositions at the same concentration of Picloram. The means were compared by Dunn's test $(p<0.05)$.

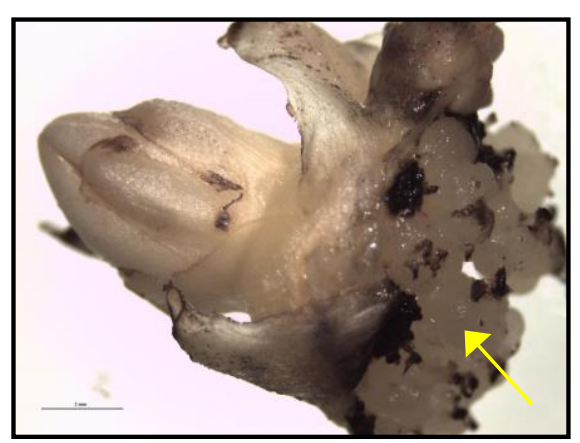

Figure 2. Friable calluses (yellow arrow) in I-15 immature inflorescences of oil palm BRS Manicoré hybrid. 

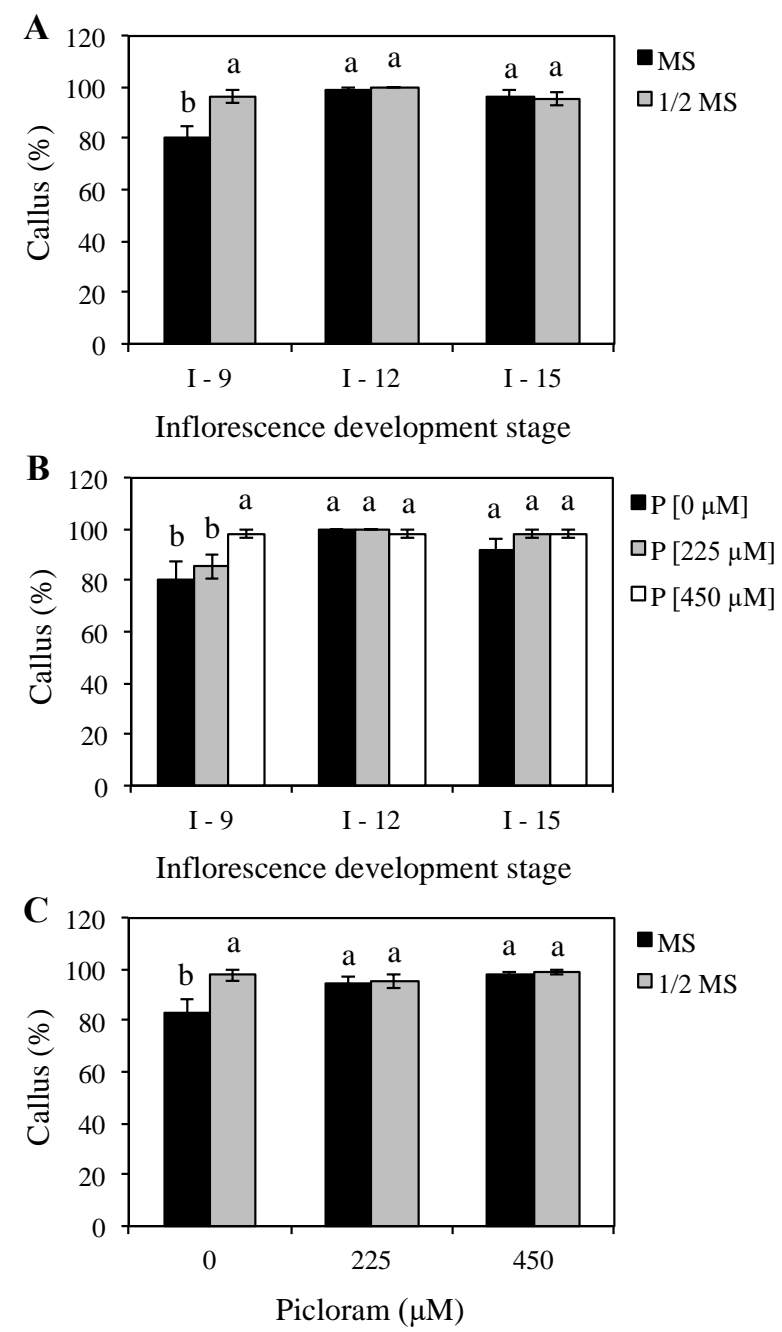

Figure 3. Effects of salt (total concentration, MS; or halved concentration, $1 / 2 \mathrm{MS}$ ) and Picloram $(0 ; 225$ and $450 \mu \mathrm{M})$ concentrations on callus induction rates of oil palm BRS Manicoré explants obtained from inflorescences at different stages of development (I-9, I-12 and I-15). The data are presented as means \pm SD $(n=6)$. In Figures $3 A$ and $3 B$, lowercase

letters indicate significant differences between treatments with different MS medium compositions (A) or Picloram concentration (B) at the same stage of floral development. In Figure 3C, lowercase letters denote significant differences between treatments with different MS medium compositions at the same concentration of Picloram. The means were compared by Dunn's test $(p<0.05)$. 


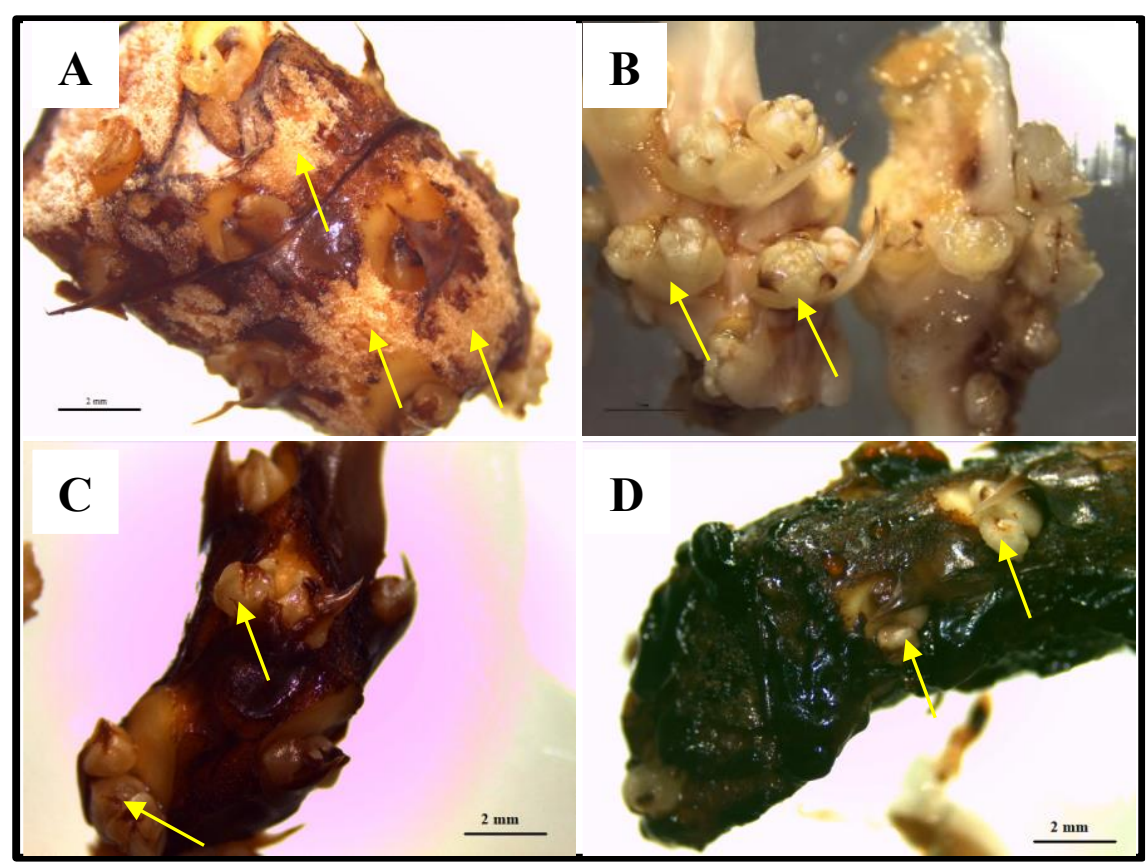

Figure 4. Morphogenesis in rachilla segments obtained from immature female inflorescences of oil palm BRS - Manicoré hybrid. Pictures were taken 45 days after inoculation in culture mediums. A, callus formation; B, floral structures; C and D, floral structures in oxidized rachilla segments

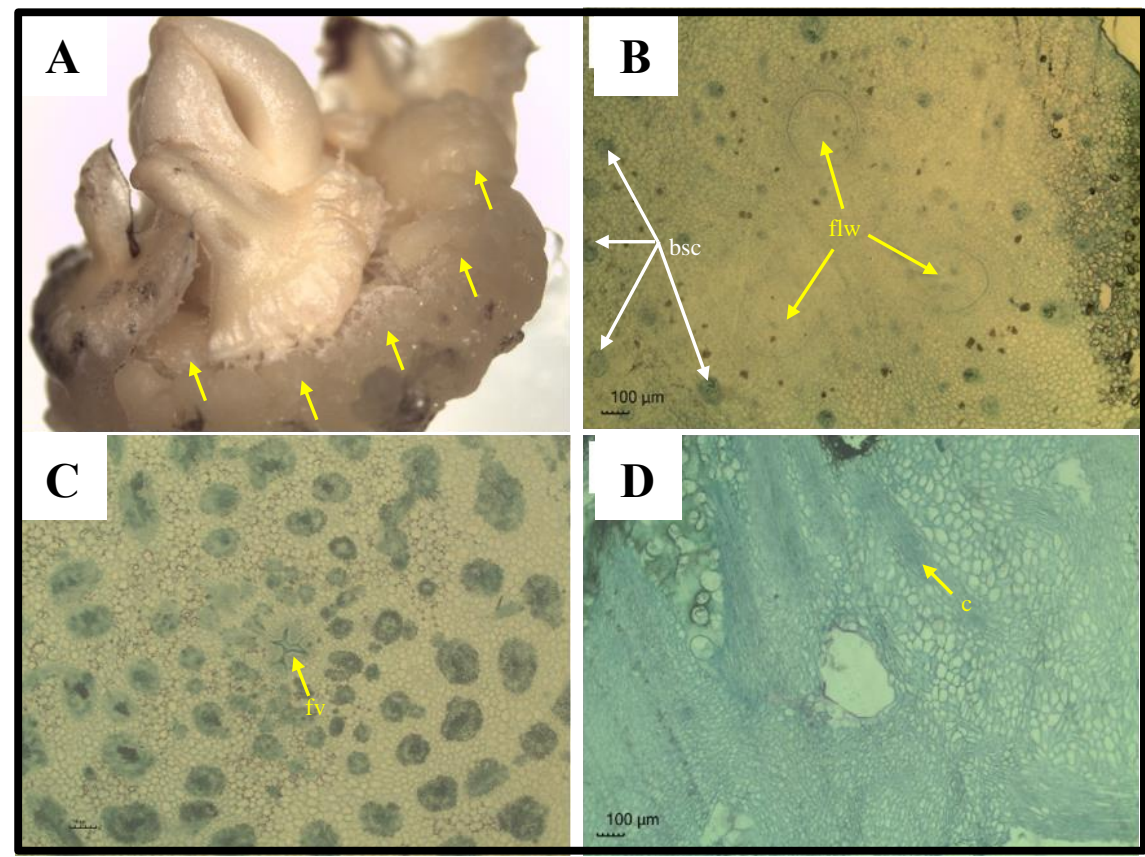

Figure 5. In vitro floral structure originated from female inflorescences of oil palm BRS -

Manicoré hybrid. A, callus formation at the base of floral structure (yellow arrows); B, histological cross - section of the floral structure (flw) surrounded by randomly - distributed vascular bundles sheath cells (bsc); C, histological median - section showing floral verticils (fv); D, histological basal - section of floral structure showing numerous callus cells (c). 


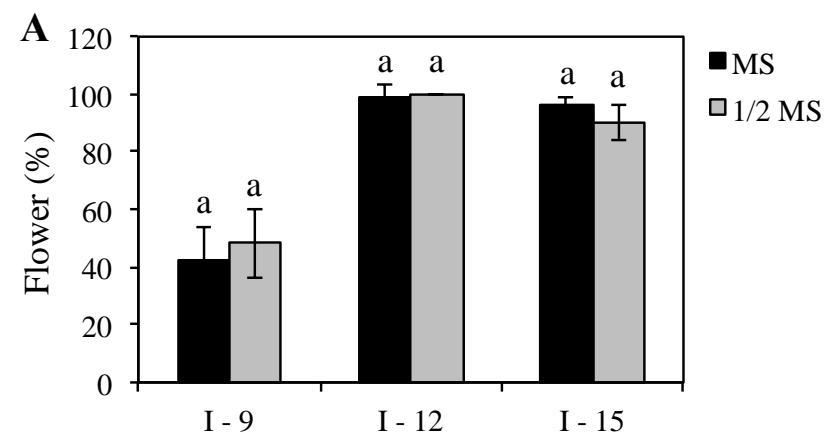

Inflorescence development stage

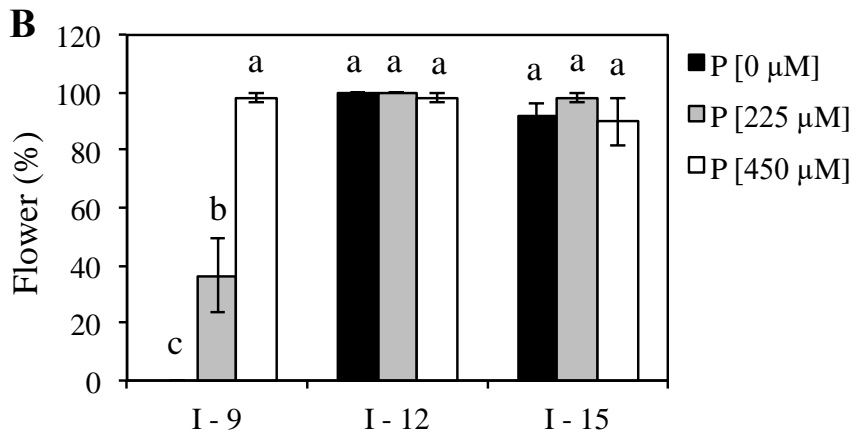

Inflorescence development stage

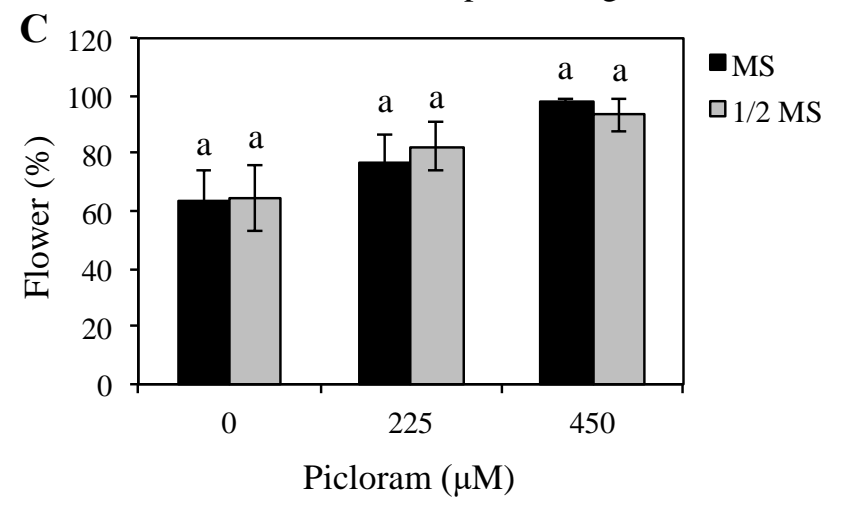

Figure 6. Effects of salt (total concentration, MS; or halved concentration, $1 / 2 \mathrm{MS}$ ) and Picloram $(0 ; 225$ and $450 \mu \mathrm{M})$ concentrations on flower induction rates of oil palm BRS Manicoré explants obtained from inflorescences at different stages of development (I-9, I-12 and I-15). The data are presented as means \pm SD $(n=6)$. In Figures $6 A$ and $6 B$, lowercase letters indicate significant differences between treatments with different MS medium (A) compositions or Picloram (B) concentration at the same stage of floral development. In Figure 6C, lowercase letters denote significant differences between treatments with different MS medium compositions at the same concentration of Picloram. The means were compared by Dunn's test $(p<0.05)$

\section{Acknowledgements}

The authors are grateful to Marborges Agroindustry S.A. (Moju, state of Pará, Brazil) for the availability of oil palm plantations to obtain the explants used in this research and to Dr. Rui Alberto Gomes Junior (Embrapa Amazônia Oriental, Belém, Pará, Brazil) for his contribution during the selection of plants and collection of inflorescences. This project was coordinated 
by J.M.M. Souza and supported by the National Council for Scientific and Technological Development (CNPq, Brazil, grant number 425383/2016-4). Scholarships were granted by CNPq (BB Boás) and by the Coordination for the Improvement of Higher Education Personnel (CAPES, Brazil; graduate scholarship to MGT Monteiro). The authors also thank CAPES / PG-Agro / UFRA for funding English-proofreading service and publication fees.

\section{References}

Angelo, P. C. S. da., Moraes, L. A. C., Sousa, N. R., Lopes, R., \& Cunha, R. N. V. da. (2007). Resgate de embriões híbridos de dendezeiro x caiaué. Comunicado Técnico $\mathrm{n}^{\mathrm{o}} 265$ Embrapa, Manaus, AM. http://www.infoteca.cnptia.embrapa.br/infoteca/handle/doc/681667

Balzon, T. A., Luis, Z. G., \& Scherwinski-Pereira, J. E. (2013). New approaches to improve the efficiency of somatic embryogenesis in oil palm (Elaeis guineensis Jacq.) from mature zygotic embryos. In Vitro Cell. Dev. Biol. - Plant, 49, 41-50. https://doi.org/10.1007/s11627-012-9479-3

Campos, R. A. S., Añez, L. M. M., Dombroski, J. L. D., \& Dignart, S. L. (2007). Micropropagação de Jatropha elliptica (Pohl) Müll. Arg. Revista Brasileira de Plantas Medicinais, 9(3), 30-36.

Carvalho, M. (2009). Embriogênese somática a partir de folhas imaturas e flores desenvolvidas in vitro de dendezeiro (Elaeis guineenses Jacq). 86 p. Tese (Doutorado) Universidade Federal de Viçosa, Viçosa.

Corrêa, T. R., Motoike, S. Y., Coser, S. M., Silveira, G., Resende, M. D. V., \& Chia, G. S. (2015). Estimation of genetic parameters for in vitro oil palm characteristics (Elaeis guineensis Jacq.) and selection of genotypes for cloning capacity and oil yield. Industrial Crops and Products, 77, 1033-1038. https://doi.org/10.1016/j.indcrop.2015.09.066

Cunha, R. N. V., \& Lopes, R. (2010). BRS Manicoré: híbrido interespecífico entre o caiaué e o dendezeiro africano recomendado para áreas de incidência de amarelecimento-fatal. Manaus: Embrapa Amazônia Ocidental, 4p. Embrapa Amazônia Ocidental, comunicado técnico, 85.

Cunha, R. N. V., Lopes, R., Rocha, R. N. C., Lima, W. A. A., Teixeira, P. C., Barcelos, E., \& Rodrigues, M. R. (2009). Domesticação e melhoramento do caiaué. In: Borém, A., Lopes, M. T. G., Clement, C. R. (Ed.). Domesticação e melhoramento: espécies amazônicas. Viçosa: Universidade Federal de Viçosa. 275-296.

De Franqueville, H. (2003). Oil palm bud rot in Latin America. Experimental Agriculture, 39(3), 225-240. https://doi.org/10.1017/s0014479703001315.

Eeuwens, C. J., Lord, S., Donough, C. R., Rao, V., Vallejo, G., \& Nelson, S. (2002). Effects of tissue culture conditions during embryoid multiplication on the incidence of "mantled" flowering in clonally propagated oil palm. Plant Cell, Tissue and Organ Culture, 70(3), 311-323. https://doi.org/10.1023/A:1016543921508

Elhiti, M., Stasolla, C., \& Wang, A. (2013). Molecular regulation of plant somatic 
embryogenesis. In Vitro Cellular \& Developmental Biology-Plant 49(6), 631-642. https://doi.org/10.1007/s11627-013-9547-3

Erig, A. C., \& Schuch, M. W. (2005). Micropropagação fotoautotrófica e uso da luz natural. Ciência Rural, 35(4), 961-965. https://doi.org/10.1590/S0103-84782005000400039

Fischer, R. A. (1922). On the dominance ratio. Proceedings of the Royal Statistical Society of Edinburgh, 42, 321-341. https://doi.org/10.1017/S0370164600023993

Guerra, M. P., Nodari, R. O., Fraga, H. P. F., Vieira, L. N., \& Fritsche, Y. (2016). Biotecnologia I. Universidade Federal de Santa Catarina, centro de ciências agrárias, departamento de fitotecnia, $44 \mathrm{p}$.

Karun, A., Siril, E., Radha, E., \& Parthasarathy, V. A. (2004). Somatic embryogenesis and plantlet regeneration from leaf and inflorescence explants of arecanut (Areca catechu L.). Current Science, 86, 1623-1628.

Krikorian, A. D. (1991). Medios de cultivo: generalidades, composición y preparación. In: Roca, W. M.; Mroginsky, L. A. (Eds.). Cultivo de tejidos en la agricultura: fundamentos y aplicaciones. Cali: CIAT, p. 41-77.

Lopes, S. C. (2013). Regeneração in vitro de híbridos interespecíficos da palma de óleo (E. oleifera x E. guineensis). 105 p. Tese (Doutorado) Universidade Federal Rural da Amazônia, Belém.

Maquiné, T. M., Queiroz, A. C., Abreu, S. C., Lima, W. A. A. de., Green, M., \& Rios, S. A. (2012). Despolpa mecânica sobre a germinação de sementes do híbrido interespecífico BRS Manicoré (Elaeis oelifera x Elaeis guineenses). In: II Congresso Brasileiro de Recursos Genéticos, 2012, Belém, PA. Anais... Belém, PA: Sociedade Brasileira de Recursos Genéticos, 2012. p. 664-667.

Murashige, T., \& Skoog, F (1962). A revised medium for rapid growth and bioassays with tobacco tissue culture. Phisiologia Plantarum, 15(19), 473-97. https://doi.org/10.1111/j.1399-3054.1962.tb08052.x

Ozias-Akins, P., \& Vasil, I. K. (1985). Nutrition of plant tissue cultures. In: VASIL, I. K. (Ed.). Cell culture and somatic cell genetics of plants: cell growth, nutrition, cytodifferenciation and cryopreservation. Florida: Academic, 2, 128-147.

Pierik, R. L. M. (1990). Cultivo in vitro de las plantas superiores. Tradução por Luís Ayerbe Mateo-Sagasta. In vitro culture of higher plants, cap.12, $326 \mathrm{p}$.

Rajesh, M. K., Radha, E., Karun, A., \& Parthasarathy, V. A. (2003). Plant regeneration from embryo-derived callus of oil palm - the effects of exogenous polyamines. Plant Cell, Tissue and Organ Culture, 81, 91.95. https://doi.org/10.1023/A\%3A1024679910085

SAS INSTITUTE INC (2014). SAS University Edition: version for Windows. Cary, NC, USA. SAS Institute.

Silva, R. C, Luis, Z. G., \& Scherwinski-Pereira, J. E. (2012). Differential responses to 
somatic embryogenesis of different genotypes of Brazilian oil palm (Elaeis guineensis Jacq.). Plant Cell Tiss Org Cult, 111, 59-67. https://doi.org/10.1007/s11240-012-0170-5

Soh, A. C., Wong, G., Tan, C. C., Chew, O. S., Chong, S. P., Ho, Y. W., ... Kumar, K. (2011). CommerciaI-scale propagation and planting of elite oil palm clones: research and development towards realization. J Oil Palm Res, 23, 935-952

Steinmacher, D. A., Clement, C. R., \& Guerra, M. P. (2007). Somatic embryogenesis from immature peach palm inflorescence explant: towards developmental of na efficient protocol. Plant Cell, Tissue and Organ Culture, 89(1), 15-22. https://doi.org/10.1007/s11240-007-9207-6

Teixeira, J. B., Sandahl M. R., \& Kirby, E. G. (1994). Somatic embryogenesis from immature inflorescences of oil palm. Plant Cell Report, 13, 247-250. https://doi.org/10.1007/BF00233313

Teixeira, J. B., Sondahl, M. R., Nakamura, T., \& Kirby, E. G. (1995). Establishment of oil palm cell suspensions and plant regeneration. Plant Cell, Tissue and Organ Culture, 40, 105-111. https://doi.org/10.1007/BF00037662

Teixeira, J. B., Sondahll, M. R., \& Kirby, E. G. (1993). Somatic embryogenesis from immature zygotic embryos of oil palm. Plant Cell, Tissue and Organ Culture, 34, 227-233. https://doi.org/10.1007/BF00029711

Thomas, T. D. (2008). The role of activated charcoal in plant tissue culture. Biotechnology Advances, 26, 618-631. https://doi.org/10.1016/j.biotechadv.2008.08.003

Thuzar, M., Vanavichit, A., Tragoonrung, S., \& Jantasuriyarat, C. (2011). Efficient and rapid plant regeneration of oil palm zygotic embryos cv. "Tenera" through somatic embryogenesis. Acta Physiol Plant, 33, 123-128. https://doi.org/10.1007/s11738-010-0526-6

Viégas, I. J. M., \& Müller, A. A. (2000). A cultura do dendezeiro na Amazônia brasileira Belém: Embrapa Amazônia Oriental. 44 p.

Zaid. A., \& Tisserat, B. (1983). Morphogenetic responses obtained from a variety of somatic explant tissues of data palm. Journal of Plant Research, 96(2), 67-73. https://doi.org/10.1007/BF02491091

Zubin, J. (1935). Note on a transformation function for proportions and percentages. Journal of Applied Psychology, Washington, 19, 213-220. https://doi.org/10.1037/h0057566

\section{Copyright Disclaimer}

Copyright for this article is retained by the author(s), with first publication rights granted to the journal.

This is an open-access article distributed under the terms and conditions of the Creative Commons Attribution license (http://creativecommons.org/licenses/by/4.0/). 